Relations industrielles

Industrial Relations

\title{
Retrospective 1947
}

\section{The Editors}

Volume 3, numéro 4, décembre 1947

URI : https://id.erudit.org/iderudit/1023588ar

DOI : https://doi.org/10.7202/1023588ar

Aller au sommaire du numéro

\section{Éditeur(s)}

Département des relations industrielles de l’Université Laval

\section{ISSN}

0034-379X (imprimé)

1703-8138 (numérique)

Découvrir la revue

Citer cet article

The Editors (1947). Retrospective 1947. Relations industrielles / Industrial Relations, 3(4), 63-64. https://doi.org/10.7202/1023588ar

Tous droits réservés @ Département des relations industrielles de l’Université Laval, 1947
Ce document est protégé par la loi sur le droit d'auteur. L’utilisation des services d'Érudit (y compris la reproduction) est assujettie à sa politique d'utilisation que vous pouvez consulter en ligne.

https://apropos.erudit.org/fr/usagers/politique-dutilisation/ 


\section{Retrospective 1947}

(Continued from page 64)

Councils are sometimes charged of being slow. Several councils' deliberations lasted several months; on an average a council takes slightly more than two months to settle a case definitely. The workers become impatient, because the various proceedings required for certification, negotiation, and conciliation have already accumulated delay upon delay. To offset such delays, the council's award may be given a retroactive effect, but the fact remains that prolonged delays frequently compel the workers to accept compromises that prove costly on retroactivity. The legislator must therefore strive to make such necessary delays as short as possible. The award should be handed down within three months from the day on which the council is formed; nowadays, proceedings may be prolonged indefinitely though the award must be rendered within the thirty days following the termination of the proceedings. Moreover, in virtue of his office, the Minister ought to be allowed to appoint the arbitrator who is to represent the employer or the employees, whenever either of the parties concerned cannot come to an agreement, within a reasonable delay, as to the choice of the person by whom they wish to be represented. Any dilatory procedure must be eradicated.

There is no doubt but that our labour relations Code should be rewritten. It must not be forgotten that if the Labour Relations Act was enacted in 1944 and has been amended twice since then, the Quebec Trade Disputes Act dates back to 1909 in its actual form. There is a great need for integration and bringing up to date. Therefore, let us hope that the legislator may fully acknowledge the importance of efficient labour laws if he is to safeguard social peace.

One must admit, on the other hand, that however important may be the laws which govern them, labour relations are, first of all, human relations. Uprightness and good faith alone allow laws to be applied with wisdom. Besides it is to be noted that employers and employees alike are becoming more and more adapted to legality and order. To realize this fact one needs merely to glance over the labour news. Those who grossly violate the actual labour legislation are becoming increasingly scarce. And above all, those who violated the law in the Province of Quebec did not reap much benefit from their illegal acts. An employer lost around a hundred thousand dollars trying to substitute an independent union to a recognized one. The union's strike at the Ayers spinning-mills, where arbitration procedure had been ignored, proved an utter failure and ended up in the Assize Court. Meat-packers' strike in which the union would not accept provincial conciliation spelled for the United Packinghouse Workers of America the loss of three or four locals. The C.C.L. shoe-workers' strike in Montreal, the calling of which constituted an open violation of the conciliation and arbitration procedure, is a lost case. We do not intend to implicate here the demands of the workers; they were well justified, since the adjustments - were granted. We simply want to bring out the fact that illegality does not pay the union any more than it does the employer. On the other hand, hundreds of unions affiliated or belonging to the C.C.C.L., T.L.C. and to the C.C.L. abided by the law and have cause for satisfaction that they have done so. Public opinion in our country can still bear the regime of law and order; thank heaven! May the successful bargaining which followed the lawful strikes at the Associated Textiles Limited, and at the Dominion Textile Company Limited not be forgotten.

This review of the year which is about to close thus leads us to conclude that, although laws can undoubtedly be perfected, the most important of all reforms still remains one of a moral nature.

THE EDITORS

\section{ASSOCIATION et CORPORATION}

Une erreur, constatée malheureusement trop tard, rendait incompréhensible le texte que nous publiions le mois dernier sous le titre «Association et corporation》. Devant la difficulté que représente la reconstitution de ce texte, nous reproduisons ci-dessous, une synthese du même arrêt, empruntée d̀ La Revue légale (R.L. 1947. no 5):

1-Le terme association \# intercalé à l'article 2D de la loi des Relations ouvrières (S.R.Q. 1941 c. 162A) signifie une réunion libre d'individus poursuivant des intérêts et des but communs, dont la formation dépend de la liberté, du choix independant du salarie, liberé de toutes contraintes et de association à laquelle on serait contraint d'adhérer, méme légalement.

${ }_{2 \rightarrow} \mathrm{Ne}$ peut être considérée comme une association au sens de la Loi des relations ouvrières, ni être accréditée comme agence de négociations auprès d un employeur, rassociation résultant, dune loi spéciale constituant en corporátion les membres dune meme profession, et abligeant toutes les personnes veulent exercer cette profession, d'en faire pantie. 3-I1 en est autrement d'une association résultant d'un syndicat formé en vertu de $1 \mathrm{a}$ Loi des syndicats professionnels S.R.Q. 1941 c 162), lorsque rien, dans la constitution, comme par la Loi des relations ouvrières.

\section{Our Industrial ...}

(Continued from page 6I)

gaged and the market in which we are interested. The justice of the established proportions may be easily tested and demonstrated. However, they are not immutable for both tool user and tool owner may, for good and sufficient reason, request their modification. What is unchangeable is the system and the true and tried principles on which it is based.

Three years of application have convinced me that the plan is the fairest that could be found. Experience has enabled us to improve it in its application and we are constantly working to perfect it.

I am firmly of the opinion that the innovation which it has brought us in the field of industrial relations may be of great benefit to the tool user, to the tool owner and to society.

\section{NOS COLLABORATEURS}

Omer Genest, D.Ph., L.Th., conseiller moral du Conseil régional Saguenay-Lac-St-Jean des Syndicats nationaux.

W.-J. Whrtehead, directeur-gérant de la Wabasso Cotton Co. Ltd, Trois-Rivières. 


\section{RETROSPECTIVE 1947}

The year is drawing to a close amidst industrial peace. Besides, the yule-tide spirit calls for harmony, even in the field of employer-employee relations. It may therefore be timely to draw up a balance sheet for the year.

Postwar economy has not yet been stabilized. How can it be otherwise when confusion prevails in international politics ? How could the American sector of world economy, the sector to which we belong, recover its equilibrium while both Europe and Asia have not yet extricated themselves from the politico-economical chaos into which Commuism has cast them ? Prices are still going up; so is the cost of living, and the workers have had to battle for a corresponding adjustment of their wages.

Fortunately, in the Province of Quebec, collective-bargaining between employers and employees has nearly always been harmonious. Our labour organizations have been very active, but they have also proved very reasonable in their demands, and this explains why the latter have been so extensively agreed to by the employers. It is also to be noted that employment in this Province has practically reached its highest level and that, on the labour market, the laws of supply and demand favours the workers.

Now, upon, the whole, how has our Provincial legislation on labour relations behaved? 1947 has been a very significant year, because since last year wages have ceased to be governed by Federal Order in Council P.C. 9384 . Nevertheless, it must be said that our labour laws have very successfully gone through the test. We will however point out a few deficiencies.

As to the Labour Relations Act, certain untoward situations arose. The long and the short of it is that this Act is quite recent. It only dates back to 1944 . It implies a profound revolution of Labour Law. Collective-bargaining is recognized as favouring the common good, since both employers and labour unions are compelled to negotiate in good faith. The right of association and freedom of association are protected by the banishment of certain forbidden practices. The most representative labour organization is legally certified as the collectivebargaining agent of the group of workers whose interests are involved. But human nature has not changed, and therefore, in a few instances, the vexations proceedings were used by certain individuals to serve their selfish purposes. The Board which enforces the Act has been a butt for numerous attacks: delays, decisions not always justified, awards suspended or reconsidered, etc... The Board's task is a very delicate and difficult one. Should there not be a code of procedure to protect the Board against the possibility of making an error ? Should it not be desired that the Board's past decisions be classified so as to be used by the Board as statute law ?

The Board is charged with certain weakness which in reality are ascribable to the Act. The Board is an administrative body, not a judiciary one. How can it put an end to forbidden practices when its awards are not enforceable? Should there not be a Labour court that would pass judgment on forbidden practices and clashes of rights ? This jurisdiction should form a special field of its own and its procedure should be as summary as possible.

Employers and employees are not altogether beyond reproach. The former hire attorneys and often cause numerous and endless hearings to take place. On the other hand, employees are faced with union pluralism which often leads to recourse to competitive means that border on electoralism.

The certification of the union as collective-bargaining agent does not settle everything. Collective negotiations between the parties must be opened. They often happen to be sluggish, but we are lead to note an appreciable improvement in the methods used by the representatives of both parties. Owing to previous agreements are litigious: wages, vacations with pay, paid holidays, union security, classification of employment or tasks and the valuation of labour standards. More than half of the collective agreements in existence have been regularly negotiated with the intervention of the Conciliation Service. A sound inquiry has revealed to us that the Provincial Conciliation Service, both at Montreal and Quebec, is quite efficient. There are but very few representations of employers' or labour organizations who do not openly acknowledge the devotedness, competence and the successes of the mediators of the Department of Labour.

In spite of their competence and.skill, these conciliators sometimes meet defeat. In such cases, in pursuance of the provisions of the Act, arbitration proceedings are resorted to. The Department reports show that over a hundred arbitration councils sat during the course of the year. About forty are still dealing with their respective cases. Some have been dissolved, others are being organized, so that, at certain periods during the course of the year, from thirty to forty arbitration councils were sitting simultaneously. Arbitration proceedings are binding in the Province of Quebec, and both Capital and Labour are fully satisfied with this. How could clashes of interests be settled otherwise if strikes and lock-outs are to be avoided ? 